\author{
Marquette University \\ e-Publications@Marquette
}

$3-2013$

\title{
How Enlightened Can a Monk Be? The Efforts of Eighteenth- Century German Benedictines to Reform Monastery and Church
}

Ulrich Lehner

Marquette University, ulrich.lehner@marquette.edu

Follow this and additional works at: https://epublications.marquette.edu/theo_fac

Part of the Religious Thought, Theology and Philosophy of Religion Commons

\section{Recommended Citation}

Lehner, Ulrich, "How Enlightened Can a Monk Be? The Efforts of Eighteenth-Century German Benedictines to Reform Monastery and Church" (2013). Theology Faculty Research and Publications. 264.

https://epublications.marquette.edu/theo_fac/264 


\title{
Marquette University
}

\section{e-Publications@Marquette}

\section{Theology Faculty Research and Publications/College of Arts and Sciences}

This paper is NOT THE PUBLISHED VERSION; but the author's final, peer-reviewed manuscript. The

published version may be accessed by following the link in the citation below.

Journal of Religious History, Vol. 37, No. 1 (February 26, 2013): 64-79. DOI. This article is (C) Wiley and permission has been granted for this version to appear in e-Publications@Marquette. Wiley does not grant permission for this article to be further copied/distributed or hosted elsewhere without the express permission from Wiley.

\section{How Enlightened Can a Monk Be? The Efforts of Eighteenth-Century German Benedictines to Reform Monastery and Church}

\author{
Ulrich L. Lehner
}

Associate Professor of Religious History, Theology Department, Marquette University, Milwaukee, WI

Aschenbrenner, B., Nachtrag zu dem Aufklärungs-Almanach für Äbte und Vorsteher katholischer Klöster ( Nürnberg, 1784), 51.

Winkopp, P. A., Ueber die bürgerliche und geistliche Verbesserung des Mönchwesens ( Gera, 1782), 81. An earlier version of this article was presented as a paper in Fall 2010 at the Notre Dame Institute of Advanced Study, and at the Intellectual History Workshop of the University of Notre Dame. I thank the research project Monastic Enlightenment and the Benedictine Republic of Letters at the University of Vienna under the able leadership of Dr Thomas Wallnig for the opportunity to discuss ideas of this paper as invited research fellow

in August 2011.

For the debate about celibacy and chastity in Germany see Picard, P., Zölibatsdiskussion im katholischen Deutschland der Aufklärungszeit. Auseinandersetzung mit der kanonischen Vorschrift im Namen der Vernunft und der Menschenrechte ( Düsseldorf: Patmos, 1975); for Catholicism and German politics see Printy, M. 
O., Enlightenment and the Creation of German Catholicism ( Cambridge: Cambridge University Press, 2009). For an overview of charges against monasticism see the still valuable essay by Sebald, A., " Die katholischen Orden in der Streitschriftenliteratur der deutschen Aufklärung (1770-1803)," in Kirchengeschichtliche Studien: P.

Michael Bihl O.F.M. als Ehrengabe dargeboten, edited by Ignatius M. Freudenreich ( Colmar: n.p., 1941), 314- 341 and especially Mühleisen, H.-O., " Der politisch-literarische Kampf um die südwestdeutschen Klöster in der Zeit der Französischen Revolution," in Die Französische Revolution und der deutsche Südwesten, edited by H.-O. Mühleisen ( Munich and Zurich: Schnell \& Steiner, 1989), 203- 263.

\section{Abstract}

This article investigates how German Benedictines in the eighteenth century tried to reform monastic life and Catholic theology by adopting various aspects of Enlightenment lifestyle and thought. It demonstrates the intellectual diversity that existed in this religious order and the order's intensive dialogue with contemporary culture.

\section{Introduction}

"Being Catholic is incompatible with being German" was a common prejudice in late eighteenth-century German literature, ${ }^{1}$ and many thought that this was especially true of monks, who were alleged to be less than proper citizens of the state and who, because of their loyalty to a foreign power (the papacy), could be considered "resident aliens." ${ }^{2}$ This was just one of many arguments brought forth against monasticism; others accused monastics of obstructing economic progress, impeding successful procreation, and, last but not least, promoting superstition. ${ }^{3}$ Many people viewed religious houses as remnants of medieval times. An anonymous writer captured this widespread view:

To spend every hour incarcerated in a dark cell and to make meditation the reason and goal of one's daily schedule, and to be forbidden to share the results of these reflections with society, is a perversion of the order of nature; and an institution that makes such disorder its fundamental law, commits high treason against the morale of humanity. ${ }^{1}$

Religious orders did not accept this strong anti-monastic sentiment and developed strategies to modernise their communities. While such modernisation was a response to such criticism, it was even more an attempt to fulfil monasticism's ancient mission better in a modernising world of religious tolerance, nationalism, academic networks, and a diversity of opinions. By the beginning of the eighteenth century, a number of German Benedictines were working at the forefront of a reform effort that intended to update monasticism by means of erudition and, later, with the eclectic use of Enlightenment philosophy as well. Not every monk supported such a modernisation of monastic life. In fact, a substantial number of monks rejected it as too progressive, innovative, and neglectful of sacred tradition. While the reformers wanted to adapt and make monasticism attractive even to (moderate) Enlighteners, their "obscurantist" critics preferred to remain a medieval thorn in the flesh of the changing world around them. It was a clash of two worldviews. One side thought that monasticism could undergo change, could leave impractical or inhuman practices of the past behind and implement new ones, while the other rejected all such changes as devilish innovation.

When such modernising strategies were developed in accord with Enlightenment ideals in the broadest possible sense, one could call these proponents "enlightened monks." 2 The reform ideas of the monks not only pertained to new forms of community life and new communication structures, but also included a strong belief in individual freedom and tolerance, along with the conviction that the Church - especially monastic life - had to modernise and adapt to society. These goals were common in a subset of the religious Enlightenment that one might call "Catholic Enlightenment" or "Reform Catholicism." Catholic Enlightenment was the "apologetic endeavor to defend the essential dogmas of Catholic Christianity by explaining their rationality in modern 
terminology." ${ }^{3}$ It also intended to reform Catholicism and "its relationship to civil society" as a viable third party that balanced the views of conservatives and progressives. ${ }^{4}$ As such, it entailed an appreciation of some strands of Enlightenment thought, and was often combined with philo-Jansenist and Conciliarist tendencies. It fought against superstition, and urged more clarity in theological terminology, an appreciation of the sciences in Catholic education, a reform of the liturgy, an emphasis on biblical studies (including historical criticism), and many other issues. The variety of problems this movement addressed shows, however, that it is impossible to speak of a unified movement. Rather, it was a reform movement with a wide spectrum of views, from conservative to radically progressive. ${ }^{5}$ When it pertained to the abolition of superstitious practices, or to the promotion of exegesis, the renewal of the liturgy, or the adaption of modern means for preaching the gospel, the Catholic Enlightenment was actually continuing measures initiated by the Catholic reform that had begun in the sixteenth century. The new reformers combined such practices with the eclectic use of Enlightenment ideas for a modernisation of Catholic philosophy and theology. ${ }^{6}$ It has only been in the last decade that D. Beales' work has emphasised the importance of monasticism for the historiography of Enlightenment. Also in recent years, T. Wallnig has taken enormous steps toward integrating monasticism into the history of early modern communication networks. ${ }^{7}$

\section{The Focus}

Not every religious order was interested enough or bold enough to contend with the Enlightenment process. In France, the Oratorians, the Benedictines of St Maur, and the Jesuits (until 1750) ${ }^{8}$ seem to have been the main proponents of a reform of Catholicism that also involved the intellectual milieu; in the Holy Roman Empire one can find individuals of almost all orders that could be identified as "enlightened," whether among the Carmelites (e.g., Anton Dereser, 1757-1827), ${ }^{9}$ Capuchins (Franz Xaver Krass and Ignaz Fessler, 1756-1838), ${ }^{10}$ Franciscans (Appolinaris Sammelmann, 1770-1832 and Eulogius Schneider, 1756-1794) or even the Carthusians (Hieronymus Fürst, 1741-1791). On a larger scale, they were also to be found among the Piarists in Bohemia, ${ }^{11}$ but there, one order stood out: the Benedictines. ${ }^{12}$ Eight main reasons can be identified why the Benedictines played such an exemplary role. ${ }^{13}$ The French Benedictine congregation of St Maur in France with its grand research projects, such as the critical editions of church fathers or medieval theologians, deeply impressed the German monasteries, which soon desired to bring about a similar fusion of monasticism and erudition. ${ }^{14}$ Such projects, however, presupposed that no central rule of the order - such as a strictly defined curriculum - would impede their efforts. In other words, these projects presupposed that an abbot or community that became enthusiastic about Maurist scholarship or similar ventures would be able to follow such a program without hindrances. Since every Benedictine abbey was more or less independent, the Benedictine Order provided an environment where an abbot could freely choose whether he wanted to integrate Maurist erudition and/or Enlightenment process into his community. ${ }^{15}$ Moreover, erudition depended largely on the availability of books and other resources. In the Empire, the Benedictine abbeys were usually well endowed and could afford to foster scholarship if they wished to do so. ${ }^{16}$ The communication networks of religious orders must also not be overlooked. While mendicants like the Franciscans also maintained contact with each other over great distances, it seems to have been primarily the Benedictine houses that communicated with each other on a regular basis about theological, philosophical, scientific, and educational matters. Besides correspondence in the form of letters,

the exchange between scholars and students from different abbeys, and the maintenance of common colleges or novitiates for monastic students all greatly contributed to a Benedictine transfer of knowledge. For example, the monks of St Emmeram in Regensburg or of St Blasien in the Black Forest invited professors of the French Maurist abbeys to teach their young monks sacred (Syriac, Arabic, Hebrew etc.) and modern languages. In return, some German monks studied in St Maur as early as 1723. ${ }^{17}$ 
In addition to the above, a book exchange system allowed Benedictine monks in the German speaking lands not only to receive publications from other abbeys, but also to obtain rare books or copies of manuscripts from other Benedictine libraries. This receptivity to the needs of research also motivated a number of Benedictines in the early eighteenth century, who were intrigued by the European Academy movement, to attempt the foundation of a Benedictine academy and to connect and coordinate their scholarly endeavors. ${ }^{18}$ Last but not least, these innovative ways of communicating and exchanging knowledge also made it easier for enlightened monks to correspond with their Protestant peers and thus to be part of the scientific community. Certainly not every abbot approved of such a free exchange of thought, but the reform-minded monks found ways to smuggle their letters out of the cloister. This exchange of ideas with Protestant theologians demonstrates the readiness of these Benedictines to engage with the "most pressing contemporary problems in theology, philosophy, science, and Church politics." 19

\section{Reforming Monastic Life}

The German Benedictines began supporting Maurist scholarship during the first decades of the eighteenth century. They paid a price for the rise of scholarship within their ranks, because the research projects the monks undertook required a different time schedule and a different practice of scholarship than their traditional annalist work. For example, a monk working on a critical edition of the works of a medieval theologian would need additional time, because he not only had to write down current events in the monastery chronicles, but also had to compare manuscripts, critically select the oldest and most reliable ones, write a commentary and critical apparatus, consult libraries and scholars about their opinion, etc. This transformation in historiographical practice contributed, from the mid-eighteenth century onwards, to a change in the mentality of the erudite monks, who preferred to pursue their scholarly vocation rather than their liturgical praise of God in the choir. ${ }^{20}$ For many of them, community prayer had become a secondary vocation that ranked behind scholarly work. It was, to put it bluntly, a reversal of St Benedict's motto "Pray and Work." A good example of this is the historian Roman Zirngibl from St Emmeram in Regensburg, who complained in a letter:

Instead of studying with sincerity, I have to go to the choir day and night, and must submit myself to things that are incompatible with my age and my ... sick body. Since we have the most nonsensical daily schedule, I have a bit over an hour daily which I can use for historical research. ${ }^{21}$

The secular work and pace of life that infiltrated the monasteries also influenced the manner in which monks employed their leisure time. Particularly in the last quarter of the eighteenth century, one can find numerous cases in which religious demanded that recreation time should cease to be controlled by clocks or rigid religious rules, such as going on a required walk in pairs. Monks longed to do things that really relaxed them, such as playing musical instruments, spending time with their pets, or breeding birds. In short, the monks wanted a private life that was not controlled by a religious schedule. ${ }^{22}$ It was also highly popular to use recreation time for playing billiards or cards. ${ }^{23}$ For example, Aegidius Jais of Benediktbeuern (1750-1822), was famous for the development of new catechetical strategies and well acquainted with Enlightenment writings, but also profoundly trained in oriental languages, hermeneutics, and exegesis by the Maurist Jean-Charles Lancelot (d. 1781). ${ }^{24}$ In addition, he was apparently an experienced player of Sheepshead, who advised the novices of the Bavarian Benedictine Congregation:

One has to have a certain disposition if one wants to play right. Expect to lose three to four florins. If you do not, your heart will be angry if you lose; one has to be somewhat willing to lose ... You should not play too anxiously, otherwise it is boring - but also not for too much money. ${ }^{25}$

Although gambling had become normal and accepted, a serious reflection such as the one Jais attempted, was rare. In most cases, games of chance were regarded as permissible recreation. However, because this was never 
theologically grounded, it led to imbalance. Because gambling was an import from the world outside the monastery walls, it soon created the same tensions within the religious community that it wreaked outside the cloister. Monks even became so fond of the game that the sick were abandoned at recreation time, factions developed within the community, and religious duties were abandoned. ${ }^{26}$ This certainly does not imply an intentional acceptance of some Enlightenment philosophy. Nevertheless, behind it stood the idea that monasticism must radically reflect civil society, including all its various ways of relaxing and entertaining its members.

As a consequence of the worldly influence of the Enlightenment process and of eighteenth-century culture as a whole, enlightened monks also began to question specific monastic traditions that clashed with their new world view, for example the monastic tonsure. Many reformers felt embarassed to have their heads almost entirely shaved; for them it was not only impractical, but a remnant of medieval barbarism, of a piety that was exterior and not interior. In short, it was a sign of monkish superstition and backwardness. Instead, these monks were in favor of choosing individual hair styles, curly long hair, and wigs. ${ }^{27}$ Traditional Benedictines, however, supported the tonsure and saw in it a symbol for the crown of thorns of Jesus Christ. ${ }^{28}$ For them monastic traditions had a hidden, allegorical meaning, which the reformers were abandoning for the sake of utilitarianism and a literal interpretation of texts and practices. In line with these findings, it is interesting to note that it was especially the exiled Scottish monks of Regensburg, Erfurt, and Fulda (who were heavily influenced by Scottish philosophy) who spearheaded the reform movement. It was these monks who first abolished humiliating punishments and obligatory tonsure, and proposed a "purified religion, healthy reason, and literature." 29

The desire to adapt monastic life increasingly to the outside world did not stop there. Even traditional cuisine and monastic dining customs came under attack. Relying on contemporary medical judgments, the food was considered too heavy and unhealthy. Obligatory fasting and the practice of eating in silence were targeted as outdated, superstitious, and unnatural. However, only a few abbeys went as far as Melk Abbey did, where monks began to eat meat during Lent as early as 1784; and, by 1786, round dining room tables had been introduced together with the encouragement to converse during mealtimes. The latter measure abolished the ancient custom of "holy silence" (but with a table reading) during meals. The enlightened reformers of Melk argued that monasticism should reflect the life of the world and should not suppress human nature, but let it develop freely, and be liberated to serve God in intelligible, purified worship. ${ }^{30}$ In Salzburg, Enlightenment theologians like Jakob Danzer (1743-1796) and August Schelle (1742-1805) preferred to eat their meals in a heated room apart from the other monks of their communities. As scholars, they wanted to entertain guests in their rooms and, therefore, favored a lighter cuisine with less meat. ${ }^{31}$ This clearly illustrates that many enlightened monks no longer regarded the cell as a place of sacred solitude, but as a private apartment that functioned as bedroom, living room, and office. ${ }^{32}$ When Benedictine professors consequently also desired to be clothed like their secular counterparts rather than in the monastic habit, it buttressed the claim that enlightened monasticism was on its way to becoming very worldly. ${ }^{33}$

The most visible sign that monks were opening their monasteries to the world, however, was the fact that some received permission to go on grand tours. While a medievalist might counter that traveling monks were nothing out of the ordinary, one can point to a distinctive difference between the medieval travel of monks and these grand tours. Travel became detached from any religious connections, so that a monk's journey might look very much like the tour of an adolescent nobleman. Like the young nobility, the monk's tour aimed at acquiring knowledge and connections. Therefore, a monk who returned from a tour was not required to remain silent about his encounters with the world, nor would he have to undergo a demeaning penance for having failed to fulfil all monastic obligations during his voyage. ${ }^{34}$ Indeed, he was expected to talk about his experiences, as long as they were morally appropriate. Monks had now become tourists. One of the first monastic grand tours was that of Angelo Querini (1680-1755). For four years, from 1710 to 1714, this future Cardinal travelled with his 
brother through Germany, Belgium, the Netherlands, France, and England. He visited such Protestant theologians as John Clericus; Jansenists like Quesnel; Anglicans, including Gilbert Burnet and Isaac Newton; and also some of the great Catholic minds in St Maur, as well as Fenelon. ${ }^{35}$ Oliver Legipont (1698-1758) of Cologne was an outspoken defender of the grand tour. For him, travel was the equivalent of a conversation with a landscape, a culture, and, especially, with the scholars residing in such areas. Such a tour served to broaden the mind, to decrease ignorance, and to build up a scholarly network. ${ }^{36}$ This urge to converse with people beyond monastery walls increased exponentially among Benedictine scholars. Nevertheless, if a monk wanted to exchange letters with a Protestant or - much less common - with a woman, that would cause problems or, at least, arouse the suspicion of his superiors. While the first category of correspondence might lead a monk to become attracted to the Protestant creed and defect, the second might well be interpreted as a romantic or sexual interest in the female interlocutor. When Laurenz Doberschiz (1734-1799) of Kremsmünster happened to be in Bologna in 1765 for legal business, he secretly met the famous physicist Laura Maria Caterina Bassi (17111778). Although in doing so he had broken an important monastic regulation that forbade monks to privately or secretly meet with women, Doberschiz had no difficulties with his conscience. Instead, his behavior illustrates the increasing self-confidence of enlightened monks and their rejection of rules they perceived to be nonsensical. When Doberschiz met Bassi, he believed his desire to satisfy his intellectual curiosity posed no conflict to his vows. Naturally, his traditionally minded confreres would not have regarded his actions as virtuous, but as wicked.

Secretly I departed from my companions, and our German guide had to bring me to the house in which I could find what I looked for, namely a rarity who, although not as precious, was certainly more extraordinary than a female saint, since where can you find an erudite woman? Nevertheless, I really have found her. It was the famous Doctor Catharina Laura Bassi de Bassi ... . Her husband is a medical doctor, and I was immediately asked to come into a very nice parlor with many mathematical instruments ... . After she chatted in Italian about many things for quite some time, we finally started to talk in Latin, and I had to work really hard to keep up with her speech ... she talked so incomparably beautifully and fast; nevertheless, so sublimely, that I have to confess that I have never heard a man talk like her. ${ }^{37}$

The travel of monks was a symptom of the growing dissatisfaction with a solitary, cloistered life, but also a sign that the erudite monks valued their scholarly vocation almost more than their religious one. Often monks did not accept a superior's denial of a voyage and would travel without the required permission. For example, Valentin Rathgeber (1682-1750) set out from Banz in 1729 for a nine-year-long tour through Europe to learn new methods of composing music and to find publishers for his pieces, and Sanderad Müller (1748-1819), in 1780 , leveraged a business trip to Austria into a grand tour to Sicily, where he acquired ancient archeological artifacts. ${ }^{38}$ (Such an offense could have been punished with incarceration and in the worst-case scenario, with life imprisonment.) Even monks who were not engaged in monastic reforms and had no interest in the Enlightenment process began to take leaves from the cloister in order to visit friends and family, to listen to music and to dance, or to play cards in taverns. One can find also ample evidence that many women's monasteries had similar issues. While this does not demonstrate lifestyle changes caused by Enlightenment ideals, it does show the growing influence of eighteenth-century secular culture and a sub-culture within religious communities that, in many cases, marginalised traditional monastic values. ${ }^{39}$

\section{Reforming the Church}

Reforming the monastery was not enough for the intellectual leaders of the Benedictine Enlightenment. They aspired to contribute to a reform of philosophy and theology as well, and with it the Church. By 1740, a substantial number of Benedictines at the University of Salzburg, which was run by the order, supported the 
ideals of a Catholic Enlightenment as Ludovico Muratori (1672-1750) envisioned it. These monks, with the support of important secular clergy and laypeople, not only began emphasising the study of natural sciences, but also introduced experimental physics into the curriculum, making Salzburg one of the first German institutions of higher learning to do so. Moreover, they advocated a philosophy freed from scholastic school trifles that could help to make the faith intelligible to their contemporaries. Making the faith intelligible is just what the eclectic-dogmatic system of the Protestant philosopher Christian Wolff (1679-1754) had promised. ${ }^{40}$ While Gregorius Rothfischer (1720-1755) had used Wolff for building a philosophical system as early as 1743, Andrew Gordon (1712-1751) of Erfurt was defending Wolff publicly by 1745, and Lorenz Manzl of Salzburg (1716-1779) was teaching natural theology according to Wolff by $1752 .{ }^{41}$ Manzl's dissertation, which shows great familiarity with Wolff and Cudworth, even embraced Leibniz' principle of sufficient reason, which at the time was gradually being received among Catholic intellectuals. ${ }^{42}$ Only in the mid-1760s when Wolffianism, especially its conception of natural law, was under heavy attack by Catholic critics, would Leonhard Gruber (1740-1810) of Metten have to disguise quotations from his philosophical hero with the invented reference: "as St Thomas Aquinas said." ${ }^{43}$ A decade later, Wolff had become so well established that Benedictines again were openly following Wolffian textbooks, even those of the Jesuit Benedict Stattler (1728-1797), and, soon afterwards, they found inspiration in the works of Immanuel Kant as well. ${ }^{44}$ Other Benedictines, e.g., Abbot Franz Rautenstrauch (1734-1785), strongly supported the Josephinist reforms in the Habsburg lands, while Benedict Oberhauser (1719-1786) became the leader of German episcopalism and received from his philoJansenist friends the honorary title "the hammer of the Ultramontanists." 45

The enlightened monks stressed an anthropological grounding of their theological enterprises; they loathed scholasticism, which they described as useless, dry and out of touch with reality; and they emphasised the study of Holy Scripture. Alternatively, as Jakob Danzer (1743-1796) of Isny put it: "I am tired of scholastic school talk - it is without any good ideas ... Is this terminology not the left over leaven ... which desecrates the temple of our superior theology?" 46 Jakob Danzer, along with Magnus Faus (1763-1810), Benedict Werkmeister (17451823), Beda Mayr (1742-1794), and Carl Prugger von Pruggheim (1763-1841), serve as excellent examples of how far the enlightened Benedictines were willing to go. While earlier generations had been much more careful, these writers were bold and original in their rejection of traditional moral, natural, and polemic theology.

In 1787 Danzer, who was teaching moral theology at the Benedictine university of Salzburg at the time, was accused of propagating a heresy, namely Pelagianism. Indeed, Danzer reduced the supernatural aspect of grace to the epistemological ability of humans to realise truth, an "Enlightenment [Aufhellung] of the soul." ${ }^{47}$ Although he did not share Pelagius' denial of original sin, Danzer approved of his optimistic view of human nature, especially that all people are "able to achieve salvation by themselves by correctly using their powers - as they are also able to achieve eternal damnation by the abuse of their powers ... ." ${ }^{48}$ Only the full empowerment of a person's moral powers, which enables perfect obedience to divine and natural law, could be realised through "grace." However, this "grace" hardly had a supernatural aspect, since he regarded it merely as an "Enlightenment [Erleuchtung] of the will," which implanted desirable images and motivations in the mind and, thus, enabled perseverance in the pursuit of virtue. This conceptualisation was shaped by numerous Enlightenment influences, and was scandalously close to Pelagius; nevertheless, Danzer responded that Pelagius' explanation of how grace worked had never been suppressed by a universal council of the Church. He implored his readers:

I solemnly swear that when I wrote my book I never thought of Pelagius ... My intention was to ... present a theological contribution about the improvement of human nature, supported by divine grace, and to connect it with psychological teachings, eliminate mysterious elements, shed light on the un-enjoyable and unimaginative elements [of the doctrine of grace], and thereby unite the practical religious teachings ... of Jesus to a superior philosophy ... . ${ }^{49}$ 
Danzer appealed in this short text to a key concept of the Catholic Enlightenment when he expressed his wish to "eliminate mysterious elements and join theology to a superior philosophy." This purging does not mean that Danzer was defending a fully developed rationalist or neologist position, but simply that he found himself linked with a key Enlightenment goal: the abolition of conceptually dark language and superstition, which he saw throughout scholastic textbooks of his time. He identified, for example, certain scholastic axioms as dark and "obscure," especially in sacramental theology, and almost always his criticism pertained to the scholastic explanation of how things worked, for example how grace operated, how bread and wine were altered in the Eucharist, how virtues were infused. Therefore, he could state that he never questioned the substance of these doctrines but only their scholastic explanations. He considered most of these classical efforts to be outdated because they rested on old-fashioned metaphysics, an ignorance of natural science, and an eclipse of modern anthropology. For him, such theological explanations were only "school opinions." 50 As such, Catholic theologians were free to deviate from them and did not need to fear persecution or censorship. Of course, Danzer's critics denied that those propositions were mere "opinions" and claimed that they were sentences of a higher theological certainty, which demanded obedient assent. Danzer, however, wanted to replace what he considered to be empty concepts of the past with a modern and "superior" philosophy that had been tested in academic discourse. Thus, the ancient mysteries of faith could lose their obscurity and instead gain luminosity and intelligibility. ${ }^{51} \mathrm{He}$ also appreciated secular ethics and insisted that Christian morality was in no way an improvement upon or a correction of philosophical morality, but merely its confirmation. ${ }^{\mathbf{5 2}}$ Accordingly, Jesus served mainly as a teacher of philosophical wisdom in Danzer's system. "The Gospels are nothing more than a school lesson to motivate people to follow the common good and to act righteously." 53

In the 1780s, a considerable number of Benedictines also became fond of the works of Immanuel Kant. It is not clear whether Bonifaz Schalk (1758-1803) of Fulda was the first Benedictine Kantian, or if Maternus Reuss (1753-1798) of Würzburg (who even visited Kant in Königsberg) had preceded him. In any case, these two Benedictines were definitely among the first Catholic intellectuals who had learned to appreciate "critical philosophy." ${ }^{54}$ In fact, it was initially Catholic institutions of learning that welcomed Kant's thought much more than their Protestant peers had done. Thus, Magnus Faus (1763-1810) of Neresheim was following in the footsteps of famous Benedictine Kantians when he argued in 1791 that reason alone was sufficient to prove the existence of God and the immortality of the soul, and that reason alone was sufficient to judge all questions concerning morality. If reason alone were truly sufficient, then the consequences would be devastating for moral theology. A teaching magisterium would no longer be needed in this system of autonomous morality. ${ }^{55}$ Moreover, Faus was not even convinced that natural religion was incomplete due to the limitations of reason (Vernunft), as Catholic tradition taught. Instead, he denied the claims that the use of reason alone would lead to erroneous religious concepts, and that reason needed the guidance of revelation:

To state that human reason (Vernunft) is itself insufficient, and the ground for false knowledge, would mean to charge God with partiality, injustice or what is even worse, incapability. ... We believe that the grounds for all errors and the ignorance of the obvious truth do not lie in the nature of reason (Vernunft), but someplace else, namely in (1) the physical law of the successive development (evolutionis) of all things, from which the development of our intellect is not excluded, (2) in poor education, (3) in the dominance of sensual knowledge ... and, finally, (4) in carelessness ... ${ }^{56}$

Benedict Werkmeister (1745-1823), also from the abbey of Neresheim, is sometimes seen as the enfant terrible of the Catholic Enlightenment, not because he celebrated the first Catholic Mass in German in the court chapel of Stuttgart in 1784 and spear-headed the liturgical reform movement, but because of his rejection of papal primacy, his call for a democratisation of the Church, his proposal to end obligatory celibacy for the clergy, and to consider the possibility of permitting ecclesiastical remarriage following divorce. ${ }^{57}$ In the 1780 s, however, Werkmeister, who later left the Benedictine order and became a secular priest, was among the first who 
appealed to Catholic theologians to reconsider the traditional view of religious liberty and to develop a more modern concept of tolerance. He was inspired, of course, by the toleration edicts (1781-1789) of Joseph II and Moses Mendelssohn's Jerusalem (1783) when he wrote down his ideas in a small anonymous book entitled Christian Tolerance for Monks and Priests. It is one of the few unambiguous demands for a universal, virtually unrestricted religious tolerance written by a Catholic and addressed to his fellow clergymen. Werkmeister hoped it would transform the widespread mentality of polemic fervor into Catholic tolerance. By "tolerance," the Benedictine understood a new worldview that was informed by an "education of the heart," while he saw "toleration" as merely a legal and civic reality. ${ }^{58} \mathrm{He}$ remarked that Jesus' teachings had never been divisive. Rather, they were about concrete moral actions, but never about the persecution of dissenters: "Jesus said: 'I send you forth as lambs among wolves [Lk 10: 3]' ..., but the lambs became wolves, feeding on the blood of those whom they should have guided back to the right path." ${ }^{59}$ In order to bring Catholic theology up to date and to make its doctrinal basis more intelligible and attractive, Werkmeister implored the clergy to support the measures of secular sovereigns of Catholic states (such as Joseph II) that would grant generous religious toleration toward Protestants and other religions. For him, civic toleration and personal tolerance were not conducive to theological indifferentism. Instead, he argued, Catholicism would profit from a diversity of theological opinions, because the encounter with different views could sharpen Catholic identity itself: "Such [Catholic] tolerance only fights with spiritual weapons, with love, harmony, and good example ... she prefers to suffer than to make others suffer ... ." ${ }^{60}$ In order to make tolerance a goal for every Catholic Christian and, thus, to educate the hearts of all the faithful towards such a transformation, Werkmeister suggested a liturgical feast of "tolerance" on Good Friday in a section dedicated to Pope Pius VI. He also anticipated Blessed John Paul II's idea of confessing the sins of the past. He implored the pope:

Confess your deeds of injustice ... Support the cause of tolerance at this critical moment, after centuries of intolerance. This is the only way to make your peace with humanity and to deserve a place in this world. ${ }^{61}$

Many German Benedictines supported irenic theology and an end of polemics toward non-Catholic denominations. While monks of the Abbey in Fulda, in cooperation with Protestant theologians, worked out a plan of how the separated churches could be reunited, Beda Mayr of Donauwörth (near Augsburg) gained public attention with his initially anonymously published First Step towards the Future Reunification of the Catholic and Protestant Churches (1778), ${ }^{62}$ which was censored and, in 1783, put on the Index of Forbidden Books. With this pamphlet, Mayr hoped to bring about a Catholic appreciation of Protestant erudition, goodwill, and good conscience and, ultimately, a diminution of polemics. Moreover, he made a compelling case for rigorous academic negotiations concerning a possible reunion. ${ }^{63}$ He foresaw an Academy of Reunification, consisting of Protestant and Catholic theologians, which would work to bring such a reconciliation about. ${ }^{64}$ The theologians of the Academy would review all divisive doctrines and then work on a common declaration that would resolve doctrinal differences. ${ }^{65}$ As a formal secretary of the Academy, the professor for reunification would be responsible for admonishing the theologians of the society to remain truthful to their goal, refraining from polemic or non-constructive criticism. ${ }^{66}$ Like many Protestants of the time, Mayr considered the notion of ecclesiastical and papal infallibility to be the central problem of ecumenism. He therefore argued that the only effective help to overcome the separation of the churches would be a re-examination of the concept of infallibility in regard to its legitimacy and extension. ${ }^{67} \mathrm{He}$ further developed this idea of limited infallibility in his 1789 work, Defense of the Catholic Faith, and introduced there - as the first Catholic theologian to do so an ecumenical methodology. To achieve an interdenominational agreement, Mayr argued, the Catholic side could not follow the majority of its patristic or scholastic authorities in a discussion about a doctrinal difference if this majority opinion would be an impediment to a reunion. Rather, it must follow the minority opinion, as long as that would not compromise magisterially defined doctrines, and as long as it would be truly beneficial to ecumenism. ${ }^{68}$ 
Finally, another example of enlightened Benedictine theology is Carl Prugger von Pruggheim (1763-1841; Benedictine until 1793). In 1803, he published a popular two-volume set on interreligious tolerance and understanding, which includes a dialogue, "Socrates among Christians." ${ }^{69}$ In the first part of the dialogue, a parish priest tries to heal one of his parishioners from intolerance. He does so by pointing out the social circumstances that make people adhere to certain religions, namely the official religion of the state, or the faith

of one's parents. ${ }^{70} \mathrm{He}$ illustrates that it would be impious and inhumane to treat "Protestants, Jews or Turks" as obstinate heretics. Pruggheim stresses instead that they err "with an innocent heart." 71 These believers acquired their religion just like any Catholic "and want to keep it just like you ... Do they really deserve your antipathy and your ... condemnation?" 72 Moreover, Christians must learn, he insisted, that the virtuous actions of non-Christians not only deserve temporal but eternal merit. ${ }^{73}$

\section{Conclusion}

In this article, I have tried to give some concise insights into a few ways in which the enlightened Benedictine monks of Southern and Middle Germany attempted to reform monastic life and theology. Much more could be said, including how they answered the challenges of modern law, philosophy (especially Locke and Kant), or critical historiography. Above all, however, one thing should stand out: eighteenth-century monasticism was not a monolithic, intellectually inflexible body with unified ideals and goals. Nor was it passively awaiting its approaching end, soon to be brought about by Napoleon, who would be - to reverse the German historian Thomas Nipperdey's famous words - not the beginning, but the end of Enlightened Monasticism. $\underline{74}$

\section{Footnotes}

1 , , Eine Blume auf das Grab des sterbenden Mönchthums: In einer Rede gehalten vor einem versammelten Generalkapitel aller Ordensstände ( Leipzig, 1799), 32- 33.

2 The religious Enlightenment, as Sorkin, David pointed out, " attempted to renew and rearticulate ... faith, using the new science and philosophy to promote a tolerant, irenic understanding of belief that could serve a shared morality and politics." D. Sorkin, The Religious Enlightenment ( Princeton: Princeton University Press, 2008), 6. For monasticism and Enlightenment see Lehner, U. L., Enlightened Monks. The German Benedictines, 1740-1803 (Oxford: Oxford University Press, 2011). By using a gender-specific form like "enlightened monks" I want to make clear that hitherto I have not found a similar movement among female religious.

3 Lehner, , Enlightened Monks, 2.

4 Mazzotti, M., The World of Maria Gaetana Agnesi, Mathematician of God ( Baltimore, MD: Johns Hopkins University Press, 2007), 39.

5 This diversity of eighteenth-century Catholic thought seems to be neglected by historians. For an overview see J. Burson and U. L. Lehner, eds., Enlightenment and Catholicism in Europe. A Transnational History ( Notre Dame, IN: University of Notre Dame Press, 2013 forthcoming).

6 Lehner, U. L., "What is Catholic Enlightenment?," History Compass 8 (2010): 166- 178 ; Lehner, U. L., " The Many Faces of the Catholic Enlightenment," in Companion to the Catholic Enlightenment in Europe, edited by U. Lehner and M. Printy ( Leiden and Boston, MA: Brill, 2010), 1-62.

7 Beales, D., Prosperity and Plunder: European Catholic Monasteries in the Age of Revolution, 16501815 ( Cambridge: Cambridge University Press, 2003). For Thomas Wallnig's project see his website, accessed 12 February 2012, http://www.univie.ac.at/monastische_aufklaerung/en. For the history of the German-speaking Benedictines during the Enlightenment, see Lehner, , Enlightened Monks.

8 For the Jesuitical approaches to Enlightenment until 1750 see Burson, J., The Rise and Fall of Theological Enlightenment. Jean-Martin de Prades and Ideological Polarization in Eighteenth-Century France ( Notre Dame, IN: University of Notre Dame Press, 2010).

9 Münch, F. X., Der äussere Lebensgang des Aufklärungstheologen Thaddäus Anton Dereser ( Bonn: Münch, 1929). 
10 On Krass see , , "Verwahrungsanstalten der katholischen Kirchenobern in Hildesheim gegen Aufklärung und Kirchenverbesserung; oder Verbannung des Capuciner-Predigers Xaverius Krass," Archiv für die neueste Kirchengeschichte 3 (1796): 568-608; " Fernere Nachricht von dem aus Hildesheim verbannten Kapuziner-Prediger Franz Xaver Krass," Archiv für die neueste Kirchengeschichte 4 (1797): 382-384; on Fessler see Barton, P., Jesuiten, Jansenisten, Josephiner ( Vienna: Böhlau, 1978).

11 See Winter, E., "Die katholischen Orden und die Wissenschaftspolitik im 18. Jahrhundert," in Wissenschaftspolitik und in Mittel- und Osteuropa. Wissenschaftliche Gesellschaften, Akademien und Hochschulen im 18. und 19. Jahrhundert, edited by E. Amburger et al. ( Berlin: Camen, 1976), 90-91. The works of the French historian Daniel-Odon Hurel explore the Maurists in a profound way. Of his many publications, I would like to refer here only to "Dom Jean Mabillon, moine bénédictin et acteur de la république des lettres dans l'Europe de Louis XIV," Rivista du Filosofia Neo-scolastica 1 (2008): 3- 16. For the influence of Maurist scholarship on the Benedictines of Early Modern Europe see T.

Wallnig and T. Stockinger et al., eds., Europäische Geschichtskulturen um 1700 zwischen Gelehrsamkeit, Politik und Konfession ( Berlin: De Gruyter, 2012) as well as T. Wallnig and T. Stockinger, eds., Die gelehrte Korrespondenz der Brüder Pez, Vol. 1, 1709-1715 ( Vienna: Böhlau, 2010). A digital edition of the latter (one of four projected volumes) is available, accessed 12 Februry 2012, http://www.univie.ac.at/monastische_aufklaerung.

12 While it is certainly true that a number of Jesuits were successful scientists, as Feingold, M. has demonstrated in many publications, e.g., in Jesuit Science and the Republic of Letters ( Cambridge, MA: MIT Press, 2003), the Jesuits as a whole resisted attempts to reform the curriculum for their universities. While one can find certain Jesuits who were fond of the Enlightenment process or at least parts of it, they could hardly ever find support from a Jesuit institution. Not even the main Jesuit theologian of eighteenth-century Germany, Benedict Stattler, was universally accepted by his confreres (see Lehner, U. L., "Benedict Stattler," in Enlightenment and Catholicism in Europe, edited by Burson and Lehner (forthcoming, 2013)). Only in the last years of the order can one find an increasing number of enlightened Jesuits, see, for example, A. Trampus, I gesuiti e l'illuminismo: politica e religione in Austria e nell'Europa centrale, 1773-1798 ( Florence: L. S. Olschki, 2000).

13 Lehner, , Enlightened Monks, 4.

14 Hammermayer, L., " Die Forschungszentren der deutschen Benediktiner und ihre Vorhaben," in Historische Forschung im 18. Jahrhundert, edited by K. Hammer and J. Voss (Bonn: Röhrscheid, 1976), 169-170.

15 Unlike the Franciscans, who had an extremely regulated curriculum, in which Duns Scotus had to be followed as the primary philosophical authority; in Bavaria this command was renewed as late as 1771. See Kogler, T., Das Philosophisch-Theologische Studium der Bayerischen Franziskaner. Ein Beitrag zur Studien- und Schulgeschichte des 17. und 18. Jahrhunderts ( Münster: Aschendorff, 1925), 33- 34.

16 Raab, H., " Das Fürstbistum Fulda (1752-1802/03)," Archiv für Mittelrheinische Kirchengeschichte 41 (1989): 184.

17 Lehner, , Enlightened Monks, 4. For the exchange with Salzburg see Hirtner, G. and Brandhuber, C., "Zwischen Bastille und Benediktineruniversität. Rektor P. Corbinian Gärtner OSB von St Peter in Salzburg (1751-1824)," Studien und Mitteilungen des Benediktinerordens und seiner Zweige 122 (2011): 1- 112. For the exchange with Regensburg-St Emmeram see Endres, J. A., Frobenius Forster. Fürstabt von St Emmeram in Regensburg ( Freiburg: Herder, 1900), 73 ; Grill, I., Coelestin Steiglehner. Letzter Fürstabt von St Emmeram in Regensburg ( Munich: Selbstvig, 1937), 17- 18 ; Greipl, E. J., Abt und Fürst. Leben und Leistung des Reichsprälaten Johann B. Kraus von St Emmeram zu Regensburg, 1700-1762 (Regensburg: Marquardt, 1980), 40. For the exchange with St Blasien see Ortner, J. P., Marquard Herrgott (1694-1762): sein Leben und Wirken als Historiker und Diplomat ( Vienna: Böhlau, 1972).

18 Hammermayer, L., " Die Benediktiner und die Akademiebewegung im katholischen Deutschland (17201770)," Studien und Mitteilungen zur Geschichte des Benediktinerordens und seiner Zweige 70 (1959): 45- 146.

19 Lehner, , Enlightened Monks, 4, 113. 
20 On the diversity of Catholic historiography see Benz, S., Zwischen Tradition und Kritik. Katholische Geschichtsschreibung im barocken Heiligen Römischen Reich ( Husum: Matthiesen, 2003), 529- 556.

21 See Kraus, A., " P. Roman Zirngibl von St Emmeram in Regensburg. Ein Historiker der Alten Akademie (17401816)," Studien und Mitteilungen zur Geschichte des Benediktinerordens und seiner Zweige 67 (1956): 39.

22 Kainz, S., " Die Scheyrer Visitationsrezesse 1686-1758," Studien und Mitteilungen zur Geschichte des Benediktinerordens und seiner Zweige 49 (1931): 156.

23 Report of Johann, P. Maichelbeck, N. about the state of the St Peter's Abbey in the Black Forest in 1739, written in 1793, Bestand 102, Nr. 220, Generallandesarchiv Karlsruhe, Germany.

24 , , P. Aegidius Jais nach Geist und Leben geschildert ( Munich: 2nd ed. 1836), 12.

25 Kainz, , "Die Scheyrer Visitationsrezesse," 171.

26 See, for example, Drascek, D., " Tagebuchaufzeichnungen des Elchinger Benediktinerpaters Columban Luz aus den Jahren 1732 bis 1773 . Volkskundliche Untersuchungen zur Alltags - und Sozialgeschichte eines schwäbischen Klosters im ausgehenden Barock," Jahrbuch des Historischen Vereins Dillingen 98 (1996): 217- 218 ; Kainz, , " Die Scheyrer Visitationsrezesse," 163.

27 , , "Von der unter den Benediktinern heut zu Tage ausgebrochenen Trichomachie," Benediktinermuseum 2 (1791), 125- 149.

28, , " Von der unter den Benediktinern," 129.

29 , , " Die Ehrerklärung," Benediktinermuseum 2 (1791): 149- 153 ; see Maclnally, T., The Sixth Scottish University. The Scots Colleges Abroad, 1575-1799 ( Leiden and Boston, MA: Brill, 2011) for the broader context of Catholic Scottish networks until the end of the eighteenth century; for monastic prisons and other punishments see Lehner, , Enlightened Monks, 103- 120.

30 Ellegast, B., " Aufklärerische Gedanken in den österreichischen Stiften am Beispiel Melks," Studien und Mitteilungen zur Geschichte des Benediktinerordens und seiner Zweige 115 (2004): 339, 344.

31 Sattler, M., Collectaneen-Blätter zur Geschichte der ehemaligen Benedictiner-Universität Salzburg (Kempten: 1889), 532- 533 ; Lehner, , Enlightened Monks, 35- 40.

32 On the cultural changes in living quarters see again North, M., Genuss und Glück des Lebens. Kulturkonsum im Zeitalter der Aufklärung ( Cologne: Böhlau, 2003), 77-97.

33 Complaint by Kleinmayrn, J. D. of 1792 about Danzer, J. and Schelle, A., fol. 16-18, Akt 1956, Archiv der Erzabtei St Peter, Salzburg, Austria; see also Lehner, , Enlightened Monks, 40-43.

34 Cf. Rule of St Benedict, ch. 67.

35 Querini reports in detail on this trip in his autobiography, Commentarii de rebus pertinentibus ad Ang. Mar. S.R.E. Cardinalem Quirinum ( Brescia: 1749), vol. 1. On Querini's correspondence see Lauchert, F., "Die irenischen Bestrebungen des Kardinals Angelo Maria Querini O.S.B. speziell in seinem literarischen Verkehr mit protestantischen deutschen Gelehrten," Studien und Mitteilungen zur Geschichte des Benediktinerordens 24 (1902): 243- 275.

36 On the development of academic networks and communication structures among the Benedictines see Marti, H.-P., " Interkonfessioneller Wissenstransfer in der Zeit der Spätaufklärung. Zur Aufnahme der Historia literaria in deutschsprachigen katholischen Ländern," in Historia litteraria. Neuordnungen des Wissens im 17. und 18. Jahrhundert, edited by F. Grunert and F. Vollhardt ( Berlin: Akademie Verlag, 2007), 161-190 ; Lehner, , Enlightened Monks, 80-102, 146-47. For Catholic communication networks and publishing see Krenz, J., Konturen einer oberdeutschen kirchlichen Kommunikationsgesellschaft des ausgehenden 18. Jahrhunderts (Bremen: edition lumière, 2012). On the grand tour in general, see Black, J., The British Abroad. The Grand Tour in the Eighteenth Century ( Stroud: Sutton, 1992; 2nd ed. 2003); Black, J., Italy and the Grand Tour ( New Haven, CT and London: Yale University Press, 2003); Black, J., France and the Grand Tour ( New York: Palgrave Macmillan, 2003); On the Catholic Habsburg lands and Legipont see Cerman, I., " Bildungsziele Reiseziele. Die Kavallierstour im 18. Jahrhundert," in Orte des Wissens. Das Achtzehnte Jahrhundert und Österreich 18/19, edited by M. Scheutz et al. ( Bochum: Winkler, 2004), 49- 78. 
37 Doberschiz, Laurenz, Journal oder Tägliche Beschreibung iener Reise, welche in dem Jahre 1765 den 4. Sept. nach Rom und den Berg Caßin mit Erlaubniß der Oberen angetretten, und den 18. Nov. mit Gott auch glücklich vollendet hat, fol. 90-92, CCn 299, Archiv der Abtei Kremsmünster, Austria.

38 Hellmuth, M., Johann Valentin Rathgeber. Ein mainfränkischer Barockkomponist (Ph.D. Thesis, Erlangen: n.p., 1943), 19-21; on Müller, see Lehner, , Enlightened Monks, 50-51.

39 See, for example, the diary of Willibald Schrettinger of 1793, fol. 6, Schrettingeriana 2, Bayerische Staatsbibliothek München, Germany.

40 Lehner, , Enlightened Monks, 175- 180 ; for an evaluation of Wolff's "moderate" Enlightenment see Israel, J. I., Radical Enlightenment. The Making of Modernity, 1650-1750 ( Oxford: Oxford University Press), 541- 562 ; Israel, J. I., Enlightenment Contested: Philosophy, Modernity and the Emancipation of Man, 1670-1752 ( Oxford: Oxford University Press, 2006), 652- 656.

41 On Rothfischer see Lehner, , Enlightened Monks, 123- 144 ; on Gordon see Lehner, , Enlightened Monks, 187-191 ; Manzl, Laurentius, Systema Theologiae Naturalis ( Salzburg: 1752).

42 Manzl, , Systema Theologiae Naturalis, § 4, 3. On the principle of sufficient reason and its reception especially among Catholic scholastics see Gurr, J. E., The Principle of Sufficient Reason in Some Scholastic Systems ( Milwaukee: Marquette University Press, 1959).

43 Letter of Leonhard Gruber to Isaac Iselin of 26 August 1776, fol. 227-34, Nachlass Iselin, PA 98, vol. 38, Staatsarchiv des Kantons Basel-Stadt, Switzerland.

44 On Wolffianism among Catholic intellectuals see Bianco, B., "Wolffianismus und katholische Aufklärung," in Katholische Aufklärung - Aufklärung im katholischen Deutschland, edited by H. Klueting ( Hamburg: Meiner, 1993), 67- 103 ; on Stattler see my essay "Benedict Stattler," in Enlightenment and Catholicism in Europe, edited by Burson and Lehner (forthcoming, 2013).

45 Lehner, , Enlightened Monks, 155- 175 ; on Rautenstrauch see Wallnig, T., "Franz Stephan Rautenstrauch," in Enlightenment and Catholicism in Europe, edited by Burson and Lehner (forthcoming, 2013).

46 Magin, A., Jakob Danzer, ein Moraltheologe der Aufklärung. Ein Beitrag zur Geschichte der katholischen Moraltheologie im Aufklärungszeitalter (Ph.D. diss., University of Tübingen: 1943), 18.

47 Anonymous and undated report on Danzer's alleged heresies, note to paragraph 13, cgm 4265, Bayerische Staatsbibliothek München, Germany.

48 Danzer, Jakob, Beyträge zur Reformation der christlichen Theologie überhaupt und der katholischen Dogmatik insbesondere (n.p.: 1793), 110-112.

49 Danzer, , Beyträge, 115.

50 On the different grades of theological certainty (theological notes) see Caretchini, S., De valore notarum theologicarum et de criteriis ad eas dignoscendas ( Rome: Gregorian University Press, 1951).

51 Magi, n, Jakob Danzer, 91.

52 Danzer, J., Anleitung zur christlichen Moral für seine Schüler in Privatstunden, vol. 1 ( Salzburg: 1787, 2nd ed. 1791), preface (5).

53 Danzer, , Anleitung, vol. 1, § 71, 258.

54 Motsch, K., " Die Kantianer Schalk und Dickert an der Universität Fulda," Fuldaer Geschichtsblätter 23 (1930): 33- 43. Schalk has been undeservedly forgotten by historians, despite his bold attempts to reform canon law and to spread Febronianism. On Reuss, see Schwaiger, C., "Matern Reuss (1751-1798) - Kant's Apostel im aufgeklärten Franken," in Kant und der Katholizismus. Stationen einer wechselhaften Geschichte, edited by N. Fischer ( Freiburg: Herder, 2005), 223- 233 ; on other Benedictine Kantians see Lehner, U. L., "Theologia Benedictina ac Kantiana. Zur Kant-Rezeption der Benediktiner Ildefons Schwarz und Ulrich Peutinger," in Kant und der Katholizismus, edited by Fischer, 234- 261 and Lehner, , Enlightened Monks, 199- 203.

55 For the development of the concept "autonomous morality" see the excellent book by Glinka, H., Zur Genese autonomer Moral. Eine Problemgeschichte des Verhältnisses von Naturrecht und Religion in der frühen Neuzeit und in der Aufklärung ( Hamburg: Meiner, 2012).

56 See Bayrle-Sick, N., Katholische Aufklärung als staatsbürgerliche Erziehung: Leben und Werk des Volkserziehers Karl Aloys Nack OSB von Neresheim 1751-1828: mit einer Reihenuntersuchung 
katechetischer Schriften 1668-1837 ( St Ottilien: EOS-Verlag, 1995), 93-95; 370-75; for a treatment of Neresheim during the Enlightenment, including Faus, see also Kuhn, A., " Die Auswirkungen der katholischen Aufklärung am Beispiel der Benediktinerabtei Neresheim," Zeitschrift für Würtembergische Landesgeschichte 68 (2009): 287- 319.

57 The only English treatment of Werkmeister and his importance for the liturgical reform movement is Swidler, L., Aufklärung Catholicism, 1780-1850 ( Missoula, MT: Scholars Press, 1978). My forthcoming monograph on the Catholic Enlightenment in Germany will shed more light on Werkmeister's theology. 58 Werkmeister, B., Über die christliche Toleranz (Frankfurt and Leipzig [i.e. Erlangen], 1784), 2.

59 Werkmeister, , Über die christliche Toleranz, 7.

60 Werkmeister, , Über die christliche Toleranz, 192.

61 Werkmeister, , Über die christliche Toleranz, 210.

62 Mayr, Beda, Der erste Schritt zur künftigen Vereinigung der katholischen und der evangelischen Kirche, gewaget von - fast wird man es nicht glauben, gewaget von einem Mönche: P.F.K. in W. (n.p., 1778). See Lehner, U., "Ecumenism and Enlightenment Catholicism: Beda Mayr O.S.B. (1742-1794)," in Beda Mayr - Vertheidigung der katholischen Religion, 1789, edited by U. Lehner ( Leiden and Boston, MA: 2009), ix- Ixxxix.

63 Mayr, , Der erste Schritt, 14.

64 Mayr, , Der erste Schritt, 12-14; see also Lehner, , Enlightened Monks, 215- 221.

65 Spehr, Ch., Aufklärung und Ökumene: Reunionsversuche zwischen Katholiken und Protestanten im deutschsprachigen Raum des späteren 18. Jahrhunderts ( Tübingen: Mohr Siebeck, 2005), 121.

66 Mayr, , Der erste Schritt, 18- 19.

67 Mayr, , Der erste Schritt, 11.

68 Mayr, Beda, Vertheidigung der katholischen Religion: nach den Bedürfnissen unsrer Zeiten [1789], edited by U. L. Lehner ( Leiden and Boston, MA: Brill, 2009), 6- 7.

69 Prugger, Carl, Tugendhafte Gesinnungen und Thaten von Heiden, Juden und Türken, in Erzählungen für Leser aus allen Ständen, vol. 2 ( Munich, 1803), 114- 150.

70 Prugger, , Tugendhafte Gesinnungen, vol. 2: 115.

71 Prugger, , Tugendhafte Gesinnungen, vol. 2: 124.

72 Prugger, , Tugendhafte Gesinnungen, vol. 2: 130.

73 Prugger, , Tugendhafte Gesinnungen, vol. 2: 194.

74 " Am Anfang war Napoleon," in Nipperdey, T., Deutsche Geschichte 1800-1866. Bürgerwelt und starker Staat, vol. 1, edited by T. Nipperdey ( Munich: C.H. Beck, 1983), 11. 